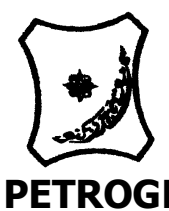

Bayero Journal of Pure and Applied Sciences, 11(1): 189 - 196

Received: January, 2018

Accepted: May, 2018

ISSN $2006-6996$

\title{
PETROGRAPHIC AND STRUCTURAL ANALYSIS OF EXPOSED ROCKS OF MUSAWA SHEET 56, NORTHWESTERN NIGERIA
}

\author{
Kitha Mbitsa ${ }^{1}$, and Musa Ado Idris ${ }^{2}$ \\ ${ }^{1}$ Department of Geology, Usmanu Danfodiyo University, Sokoto \\ ${ }^{2}$ Department of Geology, Rabiu Musa Kwankwaso College of Advanced and Remedial Studies, Tudun Wada, \\ Kano, Nigeria \\ musaadoidris@gmail.com
}

\section{ABSTRACT}

This work is among the few studies conducted in Musawa sheet 56 NE, which is part of the basement complex rocks of TudunWulli - Kankia area. The study area lies between Latitude $12^{\circ} 19^{\prime}$ $00^{\prime \prime}$ to $12^{\circ} 23^{\prime} 00^{\prime \prime} \mathrm{N}$ and longitude $7042^{\prime} 00^{\prime \prime}$ to $7046^{\prime} 00^{\prime \prime} \mathrm{N}$. Due to the continuous play of geologic processes on the earth, there is the need to continuously update the geology of the Nigeria basement complex as this has a very important economic implication especially in areas like mineral and groundwater exploration. Equally, less attention has been given to this sheet unlike other sheets within the zone. The study done in this area has revealed the various rock types and their geological characteristics: field relation, macroscopic and microscopic features as well as structural elements. Results from the study shows that the area consists of granite, migmatitegneiss and quartzite which all display a variety of colors, textures and mineralogy. Careful analysis of the distinctive mineralogy, textures, optical and structural characteristics led to the nomenclature of the rocks. The migmatite-gneiss display two petrographic varieties base on their foliation: one with linear foliation of alternating light and dark color minerals, and the other with wave like foliation. While granite is generally fine to medium grained in texture. The dominant structural trend of joints and faults in the study area are NNE-SSW and NW-SE. All these trends are consistent with the general trends of the Nigeria basement rocks. A study of thin sections of the rocks under a petrological microscope reveals optical properties peculiar to each rock type. The type and nature of structural elements associated with the rocks together with their geometry reveal that the rocks have undergone more than one deformational event. The occurrence of numerous brittle and ductile structures shows that the area has a great potential for groundwater and mineralization. But the area still experience shortage of water for domestic purposes.

Key words; basement complex, brittle structures, foliation, petrographic varieties, thin sections

\section{INTRODUCTION}

The Basement complex of Nigeria lies within the PanAfrican Mobile belt (Caby, 1989) of Late Proterozoic (500-750 Ma) age lying between the Achaean blocks of West African Craton and the Congo Craton. This Basement complex comprises of migmatites and gneisses with supracrustral relics, which have yielded Achaean (c.2700 Ma) and Proterozoic, (2000 Ma) ages (Annor, 1995; Dada et al., 1998). Intrusive to the migmatites, gneisses and supracrustal relics are the granites, termed the Older Granites which have been dated severally at 500 to $750 \mathrm{Ma}$ (Van Breenmen et al., 1977; Fitches et al., 1985; Ajibade et al., 1987; Rahaman et al., 1983; Umeji and Caean, 1984; Ferreet al., 1998; Ekwueme and Kroner, 1998). These granites are products of Late Proterozoic (PanAfrican) events that are characterized by high-grade metamorphism; folding, widespread granites plutonism and Late Transcurrent shear zones and faults (Okonkwo and Winchester, 2004).

Tudun Wulli area of Katsina State is part of the Nigeria basement complex, which is Proterozoic-Lower Paleozoic Era. The study area lies in Musawa sheet 56 $\mathrm{NE}$, situated between Latitude $12^{\circ} 19^{\prime} 00^{\prime \prime}$ to $12^{\circ} 23^{\prime}$ $00^{\prime \prime} \mathrm{N}$ and $7042^{\prime} 00^{\prime \prime}$ to $7046^{\prime} 00^{\prime \prime} \mathrm{E}$. Unlike the other adjoining area which have been studied in detail, (e.g. Kazaure schist belt, Danbatta (1999), Ibrahim (2003), Idris (2016) while Malumfashi schist belt, Rufa'i (2011) among others, not much has been done on this sheet, this therefore warrant the need to continuously update the geology of the area due to the dynamic nature of the field.

This paper will examine the general geology of the study area, and carried out a detailed structural analysis. The aims of this paper are to apprehend the lithological units, petrology and petrography as well as the structural element in terms of their geometric analysis.

\section{MATERIALS AND METHODS}

These involve all the materials used during the field mapping exercise and laboratory for petrographic analysis. Basically, the field equipment used are: Geological hammer, Compass Clinometer, tape and Global Positioning System (GPS) while the laboratory analysis include petrographic and structural analysis of both brittle and ductile structure. 


\section{Field work}

The field mapping exercise was carried out in February, 2011 and revisited in 2015; the whole exercise lasted for two week. In the field, each outcrop was observed and described based on its mode of occurrence, macroscopic characteristics, structural elements and field relation with adjacent outcrops. Hand specimens were described based on the following macroscopic features: color, texture, mineralogy and carefully labelled and plotted on the base map at the appropriate locations where the samples were collected with the use of (GPS) and the geographic coordinates of the base map. Careful observation of lithological boundaries was made by observing changes in rock units, nature of soil, vegetation, topography and thickness of overburden soil. Description and measurement of structural elements was carefully made with the aid of Compass clinometer to determine the attitudes (strike, dip values, dip directions, length and width) of outcrops and structures. Fresh rock samples were collected with the aid of geological hammer and properly labeled. Thin-section of each rock samples prepared at Ahmadu Bello University, Zaria, Geology department, thin-section laboratory, and later examined under a petrographic microscope for their mineralogical composition.

\section{Mapping of Geologic Structure}

The dominant structures encounter in the study area are; joint, fault, lineation and foliation. Faults were mapped by observing a displacement along a zone of weakness, which is upthrow in terms of normal fault and left or right displacement in strike slip fault. Another keen observation made on each normal fault was the trend of displacement, evident by the presence of plumose structure or striation, this attitude of a line on a plane is very important in the kinematic analysis of fault group (Angelier, 1979;
Marshak and Mitra, 1988; Twissand Unruh, 1998; Marrett and Allmendinger, 1990; Twiss and Moores, 2007). In strike slip fault, the magnitude of horizontal displacement was measured with a tape in some cases with a $30 \mathrm{~cm}$ ruler depending on the length. Joints were mapped by observing areas in outcrops where cohesion is lost with no relative movement of the rocks along the fracture plane. The relationship of the joints, whether parallel to dip, strike or not corresponding with either the strike or dip of the rocks was also observed. The spacing between joints in each lithologic unit was taken into consideration. The cross-cutting relationships were also carefully observed, described and recorded. All the attitude of structures values were measured and recorded for geometric analysis. The jointing pattern within a specific rock type is sometimes so consistent that it can be a useful aid for geologic mapping. On the field, not all joints are barren, but many contain coatings or narrow veins of secondary minerals, commonly quartz (i.e. joints occur as mineralized or non-mineralized).

Linear structures (lineation) and foliations were mapped carefully by identifying the trend or orientation and plunge of the lineation and plotting the data on the field map at their appropriate locations.

\section{Laboratory Analysis}

Thin sections were prepared from three representative rock samples collected in the field, (granite, gneiss and migmatite), and petrographic analysis of the thin section was carried out using a petrological microscope (model) in both PPL and XPL mode. This analysis was carried out in the Department of Geology Laboratory, Ahmadu Bello University Zaria, Kaduna, Nigeria.

The general sequence of petrographic observation adopted is described in the table 1

Table 1: Sequence for petrographic observation.

\begin{tabular}{|c|c|}
\hline No. & DESCRIPTION \\
\hline 1 & $\begin{array}{l}\text { Form and Crystallographic Properties: } \\
\text { A. crystal form if developed; } \\
\text { B. cleavage, parting, or fracture: number of cleavage and angular relationship to one another perfection } \\
\text { of cleavage, characteristic of parting and fracture; } \\
\text { C. shape of grain, if distinctive (fibrous, acicular, bladed , radiating, reticulate, tabular, platy), } \\
\text { D. inclusion, intergrowths, alteration, association with other minerals and } \\
\text { E. twinning. }\end{array}$ \\
\hline 2 & $\begin{array}{l}\text { Optical Properties are: } \\
\text { A. opaque minerals: color by reflected light; } \\
\text { B. transparent or translucent minerals; } \\
\text { - Color and pleochroism } \\
\text { - Relative index and relief } \\
\text { C. Examination under crossed nicols; } \\
\text { - isotropic or anisotropic } \\
\text { - in anisotropic mineral, interference color and determination of birefringence } \\
\text { - determination if length slow or length fast } \\
\text { D. information from interference figure } \\
\text { - uniaxial or biaxial, sign, whether positive or negative } \\
\text { - If biaxial, optical angle, dispersion, orientation of optic plane, determination of pleochroic } \\
\quad \text { formula. }\end{array}$ \\
\hline
\end{tabular}




\section{Structural Analysis}

The structural analysis of this work was carried out using these geological soft ware's, Orient 3.0.1, (1986-2015 Frederick W. Vollmer), Georose, (Yong technology international), Origin Pro. 8.5 and Global Mapper Version 15. The user manual of these software is available on line.

\section{RESULTS AND DISCUSSION}

\section{Geology, Field Occurrence and Distribution}

The area mapped consists of rocks of the Nigerian basement complex, which are Proterozoic to Paleozoic of age. The major lithologies mapped in the study area are: migmatite-gneiss and granite (Figure 1). Though, in all locations migmatite and gneiss occurred together, making it hard to differentiate the two.

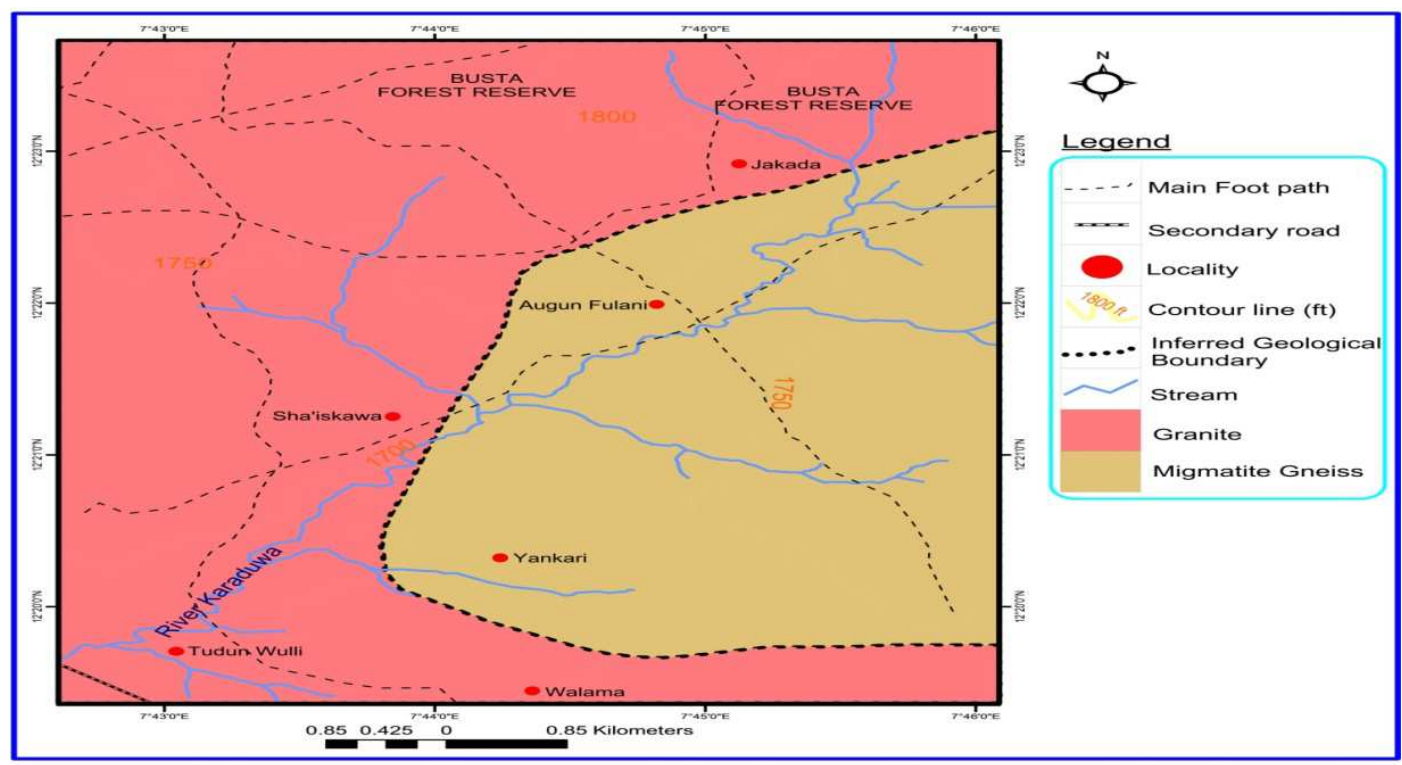

Figure 1: Geological map of the study area

Quartzite: exposures were mapped in the northeastern part of the study area, though this did not appear on the geologic map because of the size. This rock unit occurs as a narrow, elongated and faulted exposure, Regarded as breccias. The rock is properly exposed to the surface due to human activities in the area (local miners).

Migmatite-gneiss: it occupies about $44 \%$ of the study area, with most of the outcrops in southeastern part. It is grey to pinkish, fine to medium grained and also foliated. The foliations are defined by the parallel arrangement of dark and light color minerals (Agbor et al., 2012). It occurs in pocket, with their outline generally circular, whaleback, elongated in NE-SW direction. The exposures are between ( 3 to $4 \mathrm{~m}$ ) above the ground level, structures like joint, quartz vein, and were visible to the eyes. The thickness of the overburden soil in this area is about ( 2 to $4 \mathrm{~m}$ ).

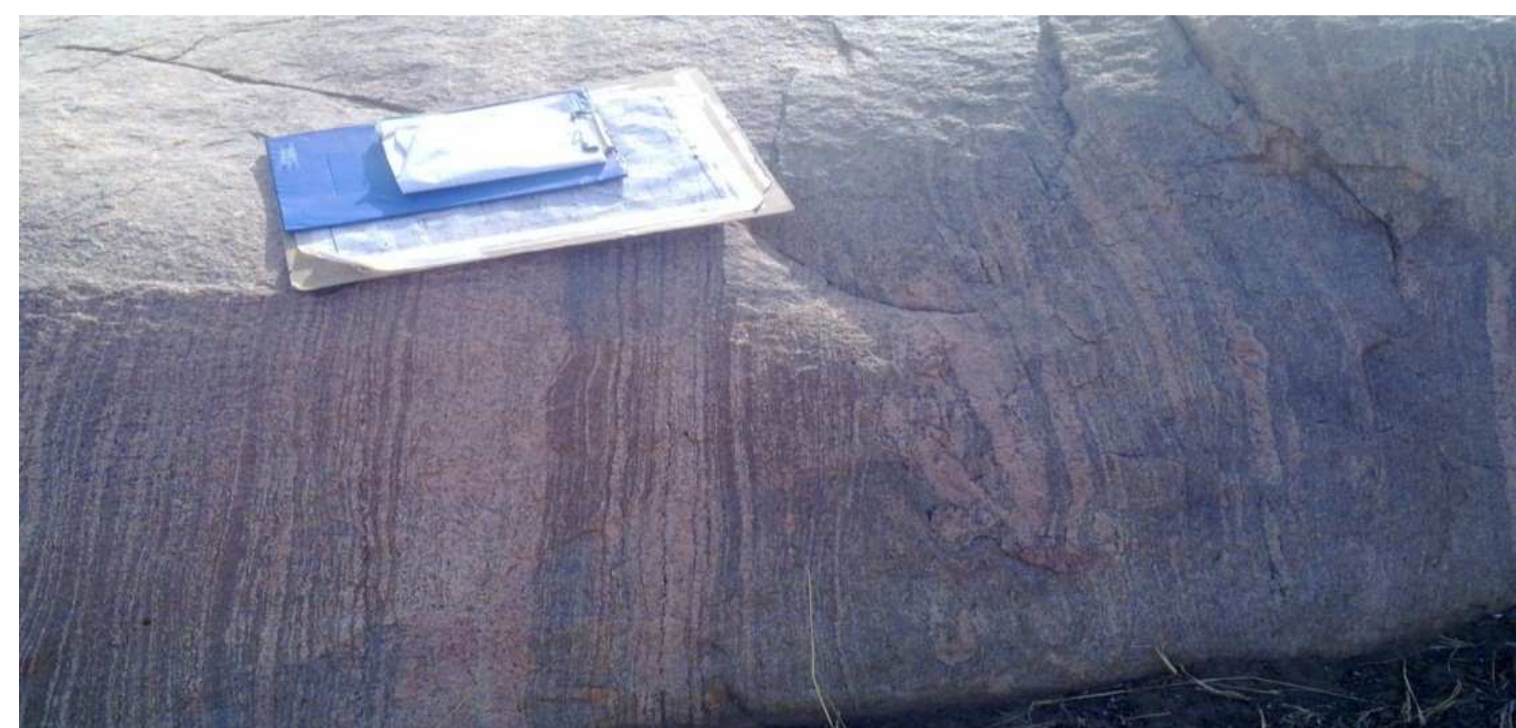

Plate I: An outcrop of migmatite-gneiss near Unguwar-Guru southern part of the mapped area (coordinates $12^{\circ} 22^{\prime} 18.9^{\prime \prime} \mathrm{N}, 007^{\circ} 44^{\prime} 46.2^{\prime \prime} \mathrm{)}$ 


\section{Petrographic Description of migmatite gneiss}

Under the microscope, the rocks show euhedral and anhedral crystals of dark and light colored minerals. The dark colored mineral is biotite while quartz is the light colored minerals. Visual estimate of minerals using hand lens show that the shiny minerals predominate (i.e. orthoclase feldspars), follow by quartz, biotite in that order. The quartz is polycrystalline, anhedral to subhedral, ondulatory extinction, partially recrystallized. Mineralogical compositions of the rock unit are orthoclase $30 \%$, quartz $20 \%$, biotite $20 \%$, and microcline15 \%.

Color: Leucocratic

General texture: fine-to-medium grain

Mineralogy: feldspar (45\%), Quartz (20 \%), Microcline (15\%).

Name: Migmatite- gneiss

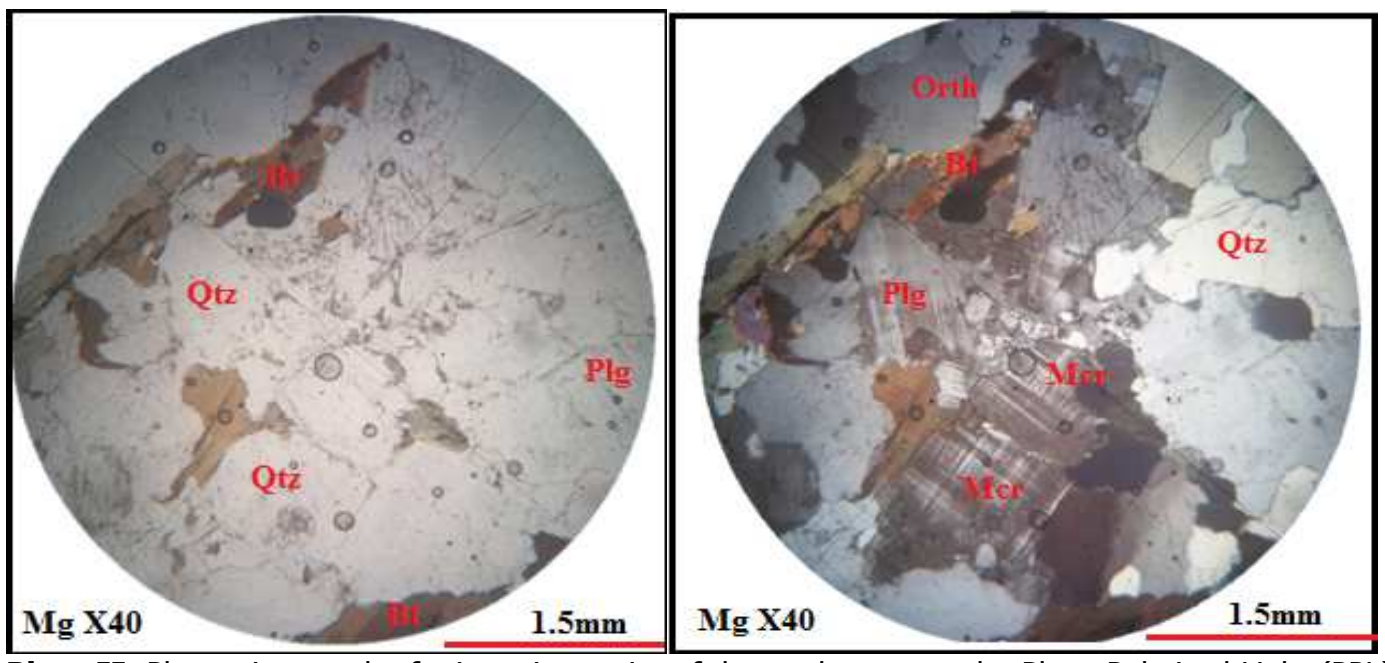

Plate II: Photomicrograph of migmatite gneiss of the study area, under Plane Polarized Light (PPL) and Crossed Polarized Light (XPL): Qtz = quartz, Bt = biotite, Mrc = microcline and Orth = orthoclase

Granite: exposures were mapped at several locations in the western part of the study area; they occur as low lying outcrops ( 4 to $6 \mathrm{~m}$ ) above farmland level, occupying about $55 \%$ of the study area and appear very massive. Structures like joint, quartz vein, pegmatite dyke, were commonly associated with the granitic exposures. The pattern of weathering on this rock exposures is mechanical (exfoliation) and the thickness of the overburden soil is about (1 to $3 \mathrm{~m}$ ), the contact between granite and migmatite-gneiss is inferred.

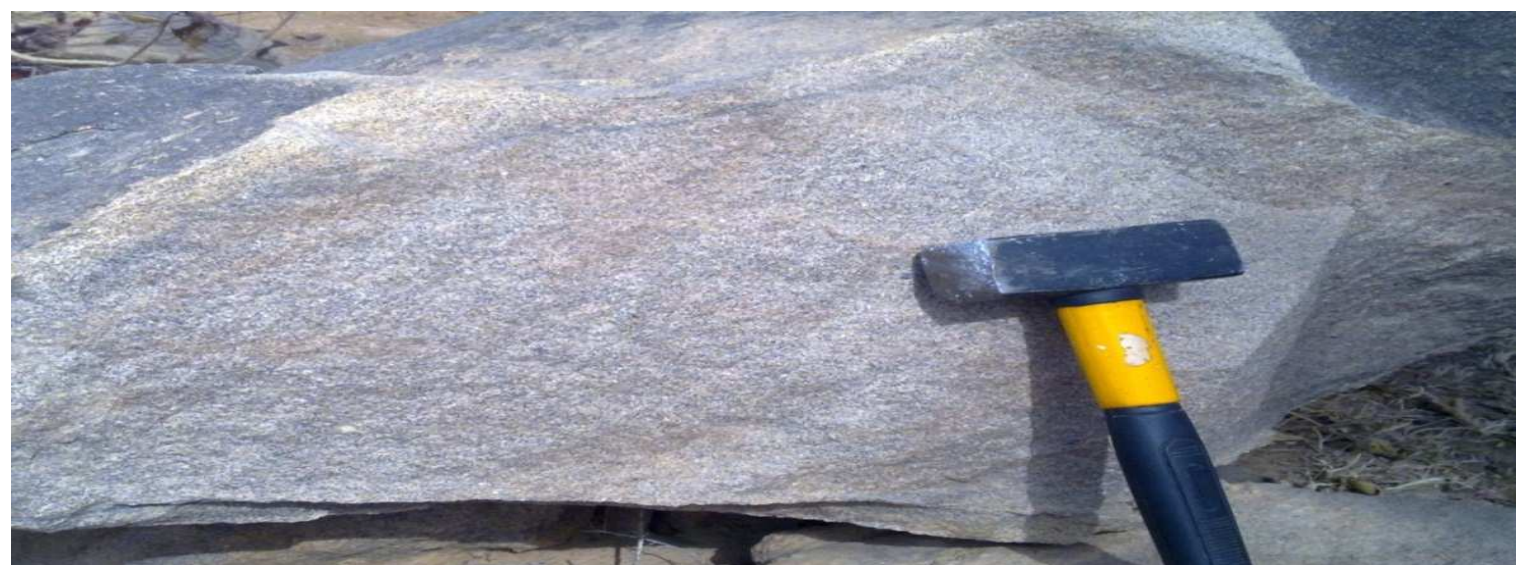

Plate III: field occurrence of granitic rock, northwestern part of Walawa village (coordinates; $12^{\circ} 22^{\prime} 45.9^{\prime \prime} \mathrm{N}$ and $\left.007^{\circ} 45^{\prime} 24.6^{\prime \prime} E\right)$.

\section{Petrographic Description of Granite Rocks}

The hand specimen of rock is grey in color (leucocratic), fine to medium grain, with the larger grain between 1 to $4 \mathrm{~mm}$, the rock is weakly or nonfoliated and appear massive. Visual estimate of minerals using hand lens shows that the shiny minerals predominate (i.e. feldspars), follow by quartz, biotite in that order.

Color: Leucocratic

General texture: fine-to-medium grain

Mineralogy: feldspar (4 5\%), Quartz (35 \%), Biotite (10\%).

Name: fine-grained Granite 
Bajopas Volume 11 Number 1 June, 2018

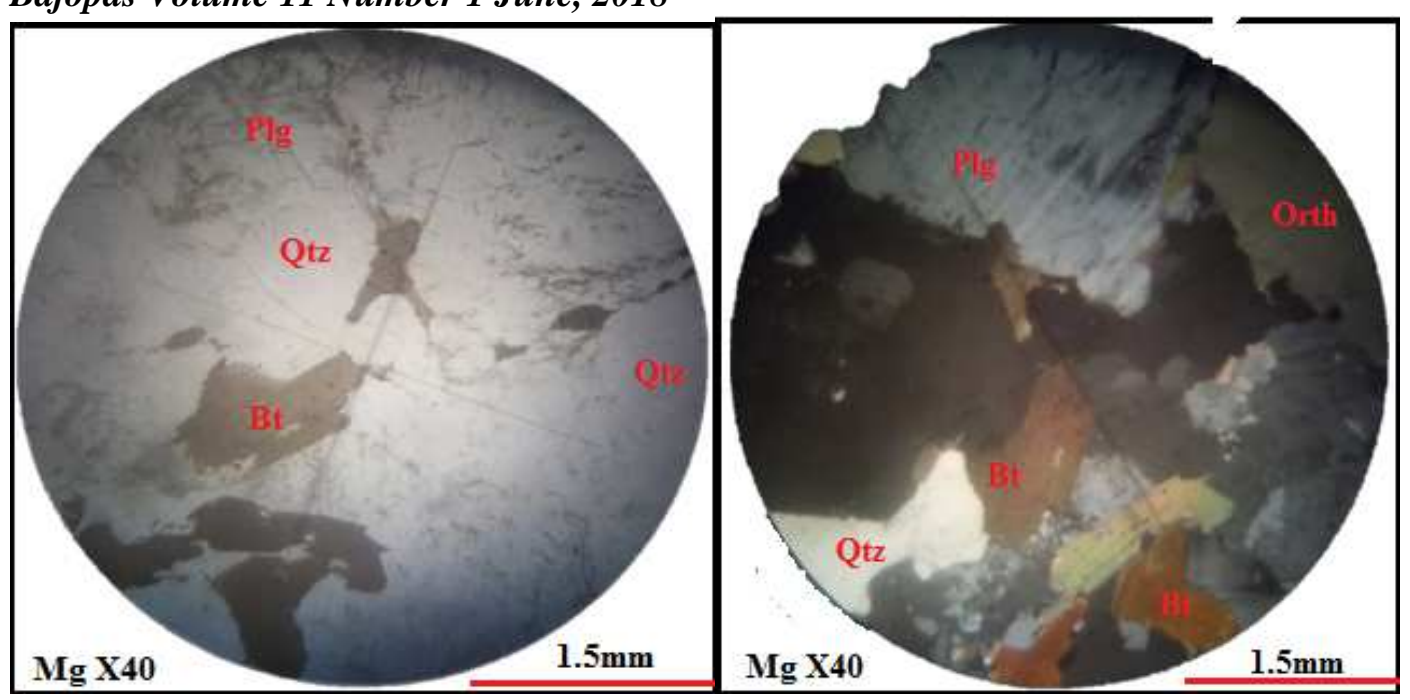

Plate IV: Photomicrographs of granite under XPL and PPL NOTE: Bt = Biotite, Qz = Quartz, Orth = Orthoclase, $\mathbf{P l g}=$ plagioclase

\section{Structural element}

The structural elements observed in the study area are associated with both brittle and ductile deformation, and believe to have formed as a result of different tectonic processes that affected the area.

\section{Brittle structures}

This refers to structures which experience a loss in cohesion after their deformation; this can be attributed to the conditioned that prevailed during the deformation.

\section{Joint}

The outcrops observed on the field are mostly jointed, and the intensity of the joints is more on granitic exposures as compared to other lithological units, the joints have approximately equal

spacing on granite exposures, with their separation between $1-15 \mathrm{~cm}$, but their trends varies from NESW, N-S, and NW-SE. Some joints penetrate vertically while others are horizontal to the surface (exfoliation) and most of them are continuous. The orientation of the joint measuredon the field ranges from 0-349, some joints plane are coated or filled with silica material probably quartz. Cross-cutting relationships were encountered at several locations which enabled us to determine the generations of joints and the relative age.

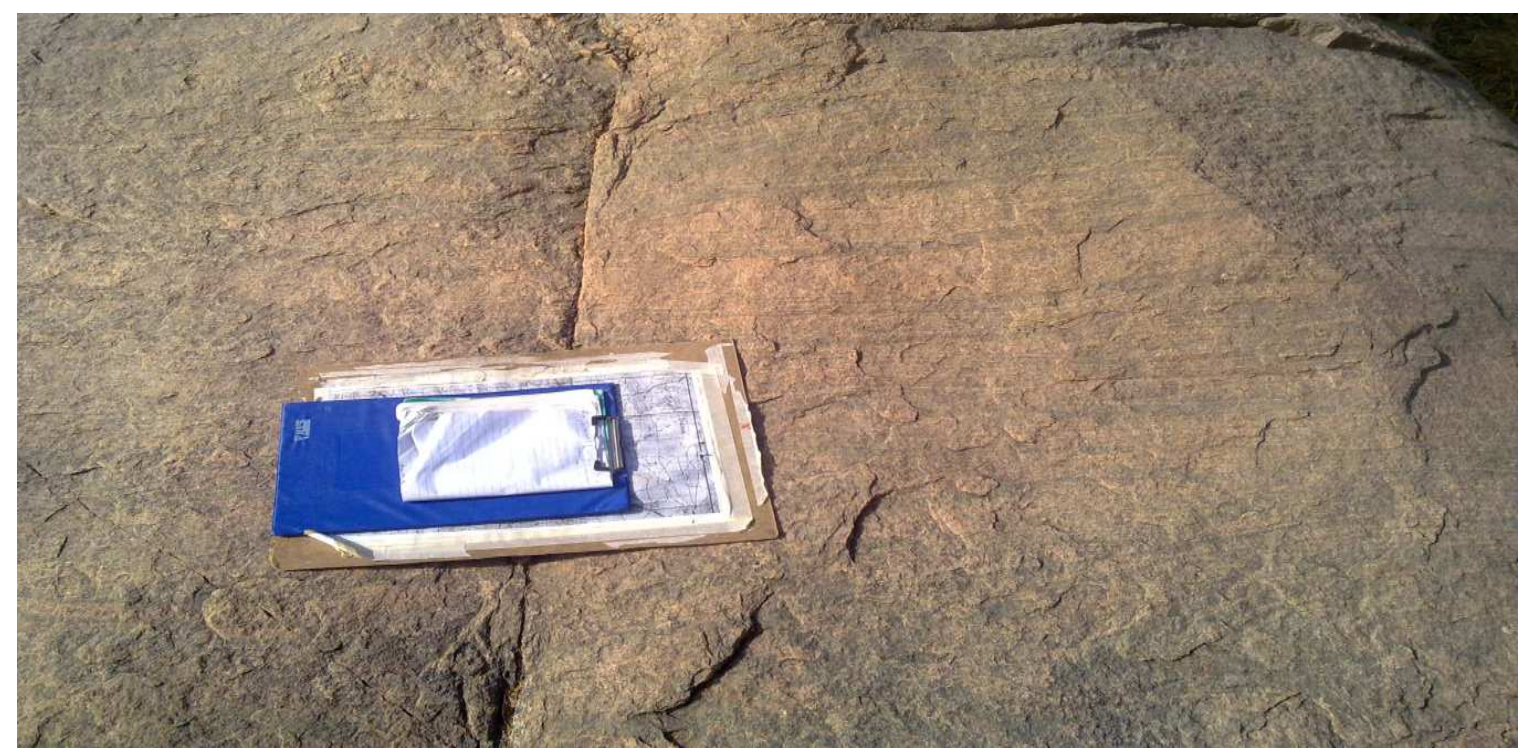

Plate VI: Photograph of a Quartz vein in granite exposure at location $\left(12^{\circ} 20^{\prime} 12.4^{\prime \prime} \mathrm{N}, 007^{0} 42^{\prime} 12.5^{\prime \prime} \mathrm{E}\right)$, width $7.5 \mathrm{~cm}$, trending NW-SE.

Geometric analysis of joint 

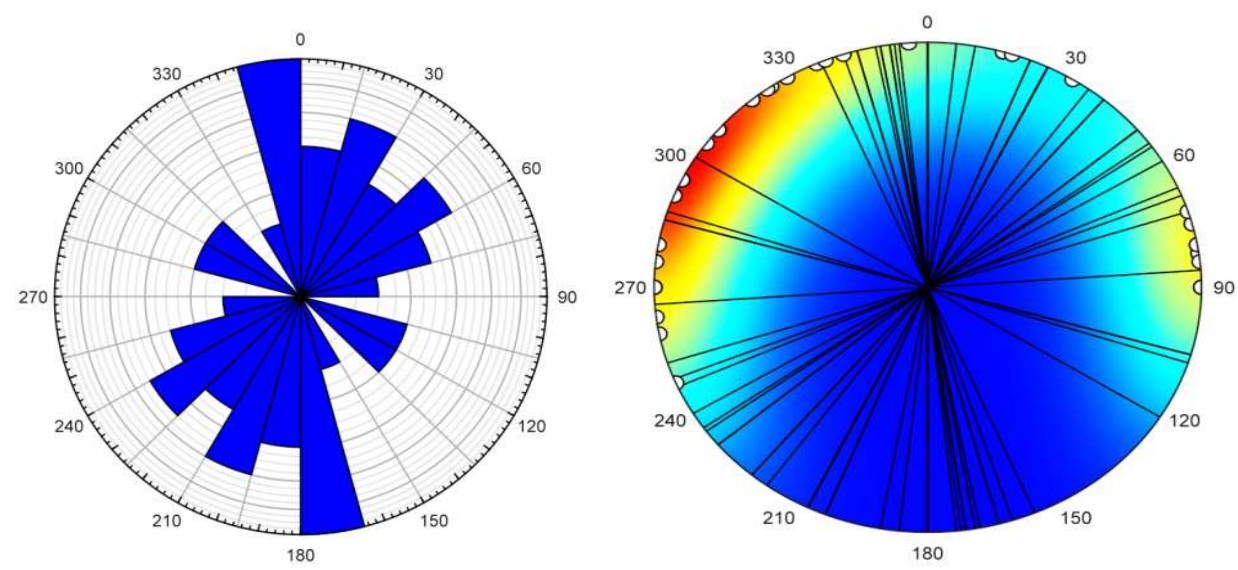

Figure 2: (A) Rose diagrams of joints in granite, (B) circular plot (directed) of joints in granite

\section{Fault}

The faults in the field were mainly at mesoscopic scale, one type of faults occur in the area, the strike slip fault, and occur mostly in granite. Dextral and sinistral faults were encountered at several locations in the study area, with small displacements of the order of $4-30 \mathrm{~cm}$. (plate VIII).

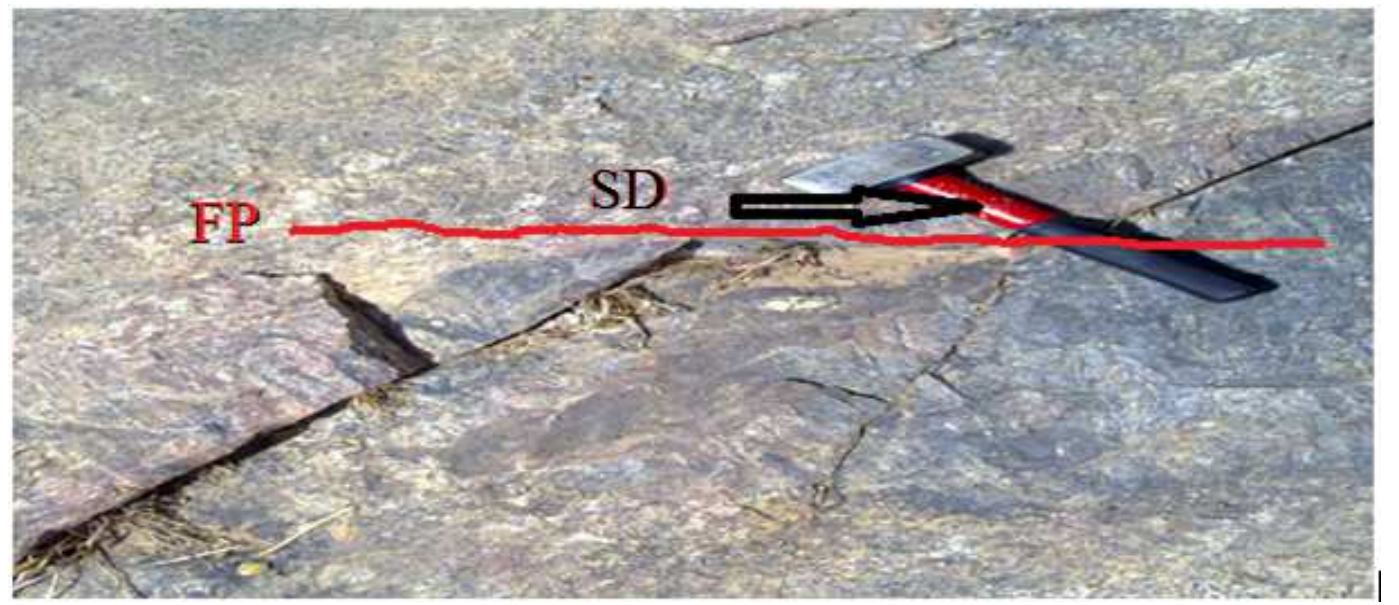

Plate VII: Photograph of a fault observed on ferroginized exposure with a displacement of few centimeters at a location of $\left(12^{\circ} 20^{\prime} 21.7^{\prime \prime} \mathrm{N}, 007^{\circ} 45^{\prime} 44.2^{\prime \prime} \mathrm{E}\right)$ (Dextral fault, $\mathrm{FP}=$ fault plane, SD = sense of displacement)

\section{Fault breccias}

This was observed in the north-eastern part of the study area, associated with ferroginzed outcrops. They were exposed to the surface properly as a result of human activities in the area (local mining). The zone of brecciasion is regarded as plane of movement, which resulted in breaking and shattering of the preexisting rock. The faulted rock is dominantly quartzite, (plate IX) the orientation of this structure on the field is $\mathrm{N}-\mathrm{S}$ direction.

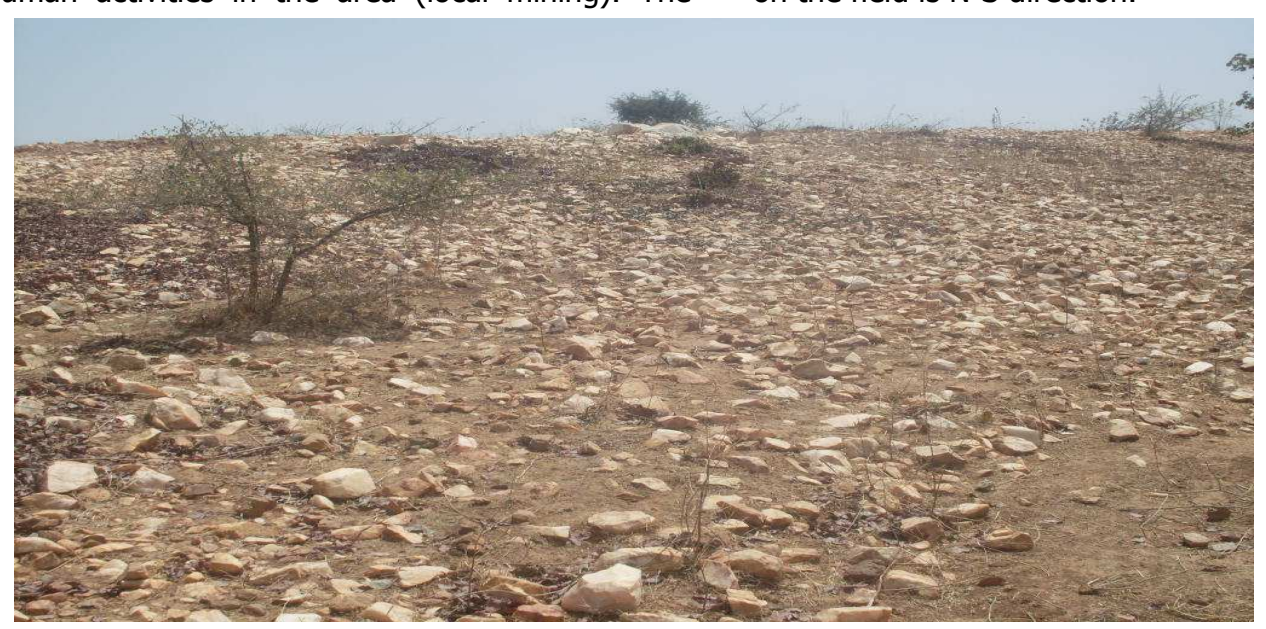

Plate VIII: Photograph of a fault breccias located north of Dogarawa village (coordinates; $12^{0} 22^{\prime} 19.2^{\prime \prime} \mathrm{N}, 007^{0}$ $45^{\prime} 01.0^{\prime \prime} \mathrm{E}$ ) oriented in N-S direction. 


\section{Ductile Structures}

\section{Foliations and Lineation}

Foliations encountered are common in the migmatites and gneisses. There are two generations of foliations S1 and S2. The development of the S2 foliations has destroyed some of S1 foliations. The S1 foliations are less repetitive and penetrative than the S2 foliations. Both types of foliations have atitude and orientation in the range of NNE-SSW (Plate IX). Lineations in the rocks are displayed by the parallel alignment or preferred orientation of dark (melanosome) and light (leucosome) coloured minerals. The dark coloured minerals are the ferromagnesian minerals (hornblende and biotite) while the light coloured minerals are the quartzo-feldsparthic minerals (quartz and feldspar) (Plate I).

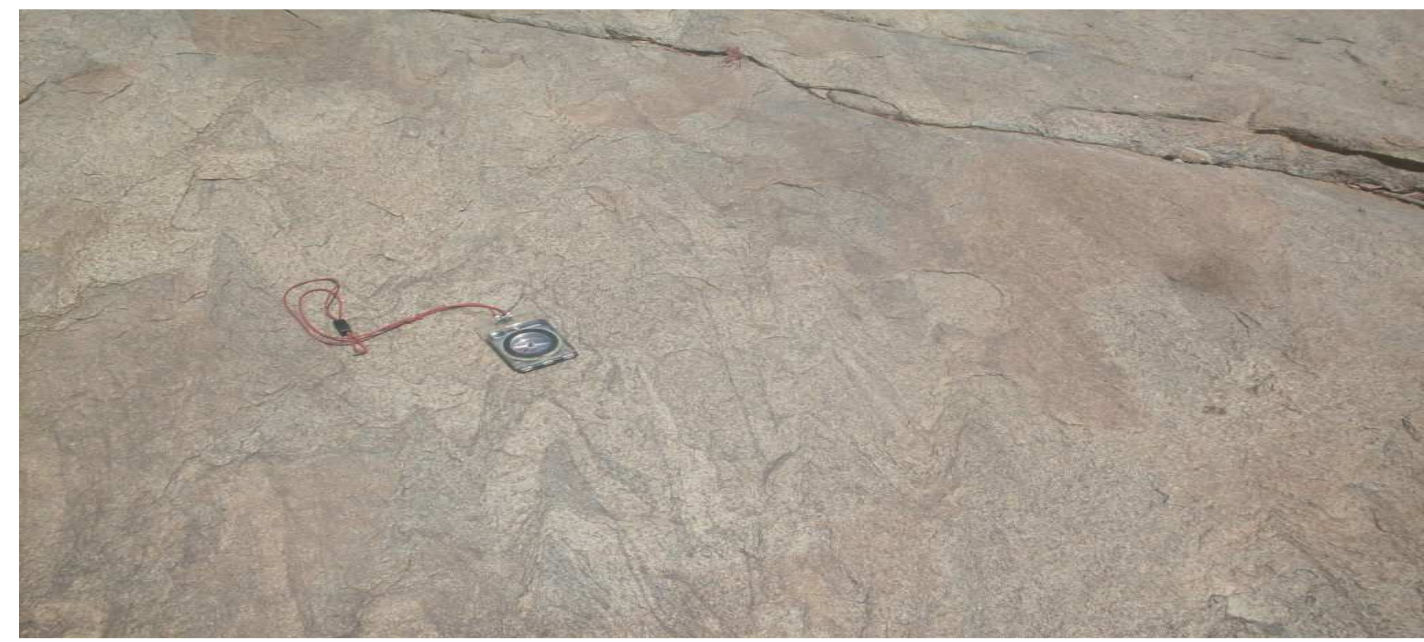

Plate IX: Photograph of foliation on Migmatite, located north of Anguwan Fulani, (coordinates $12^{\circ} 22^{\prime} 18.9^{\prime \prime} \mathrm{N}$, E007044'46.2')

\section{Conclusion}

The study area consists dominantly of migmatitegneiss intruded by the Pan-African granites. Quartzite is a minor lithology that occurs as a linear ridge. This area has been reported to be intruded by Granitic rocks of Pan- African age. This implies that the granite is younger than the migmatite- gneiss. The lithological units display different texture, minerals and structural elements which are the bases for their nomenclature. The study area is a metamorphic terrain with structures indicating that the rocks did not experience any intense deformation. The textural variation in the rocks is due to varying size and amount of feldspar crystals they contained. This in turn is a function of the petrogeneiss of the individual rock type.

The nature of the mesoscopic geologic structure in the area and their spatial attitude reveals that the rocks have undergone more than one deformational event since the time of their formation. The presence of the minor structures may be indications for major

\section{REFERENCES}

Agbor, A.T.,Shehu, O.U., Dantata, S.H., Jude, E.S., and Asema, A.I. (2012). Petrographic and Structural Analysis of Exposed Rocks of Bishini Sheet (Block 2), North Central Nigeria. Earth Science Research; Vol.2,No.1;143155.http://dx.doi.org/10.5539 /esr.v2n1p143.

Ajibade, A.C; Woakes, M.And Rahman, M.A. (1987). Proterozoic crustal development in the Pan-African regime of Nigeria. ILP Working Group 3 mid-term report. American Geological Union Monograph No 17. once at the subsurface. The dominant trend of joints is (NNE-SSW). This conforms to the imprint of PanAfrican Orogeny. The intensity of joint in the study area indicates that the area may have a great potential for underground water and solid minerals.

\section{Acknowledgments}

We thank the Department of geology, Ahmadu Bello University Zaria, then under the headship of Dr. U. A. Danbatta, (now Prof. U. A. Danbatta) for their guidance and advice during the final year field work exercise. And also, our gratitude goes to the project supervisor then Dr. S. A. Alagbe (now Prof. S. A. Alagbe.) Not to forget Mr. Robert Lamja, for preparing the thin section of the rock samples, we appreciate his effort. My acknowledgment will be incomplete without recognizing the effort of our colleagues; Joseph Bitrus, Rilwan Moh'd, Abubakar Saidu and Henry. Finally, our deepest appreciation goes to Prof. U.A. Danbatta for reading through the first draft and offering suggestions. God bless you all.

Annor, A. E. (1995). U-Pb zircon age for KabbaOkenegranodiorite gneiss: implication for Nigeria's basementChronology. African Geoscience Review, 2, 101-105.

Bain, A.D.N., (1926). The Geology of Bauchi Town and Surrounding district, Bull. Geol. Surv. Nigeria No. 9.

Bucher, W.H., (1944). The stereographic projection, a handy tool for the practical geologist. Journal of Geology, v. 52, n.3, p. 191-212.

Caby, R. (1989). Precambrian terrains of BeninNigeria and Northeast Brazil and Late Proterozoic SouthAtlanticrift. Geol. Soc. American Spec. Paper, 230, 145-158. 
Cheeney, R.F., (1983). Statistical methods in geology. George Allen and Unwin, London. 169 p.

Dada, S. S., Briqueu, I., and Bireck, J. L. (1998). Primordial Crustal Growth in northern Nigeria: Preliminary $\mathrm{Rb}-\mathrm{Sr}$ and $\mathrm{Sm}-\mathrm{Nd}$ constraints from Kaduna migmatite-gneiss complex. J. Min. Geol., 34, 1-6.

Danbatta, U. A. (1999). The Geotectonic Evolution of the Kazaure Schist Belt in the Precambrian Basementof NW Nigeria.Published Ph. D. Dissertation.Ahmadu Bello University, Zaria, 289p.

Davis, J.C., (1986). Statistics and data analysis in geology.Wiley, $646 \mathrm{pp}$.

De Sitter, L.U, (1956). Structural Geology.McGraw-Hill Book Company, Inc., London, New York, Toronto.552 p.

Eborall, M.L., (1976). Intermediate Rack from Older Granite Complexes of the Bauchi area, Northern Nigeria Kogbe(ed), In Geology of Nigeria, Elizabethan Publ. Co., Lagos, pp 6574.

Ekwueme, B. N., and Kroner, A. (1998). Single Zircon evaporation ages from the Oban Massif, SoutheasternNigeria. J. Afri. Earth Sci., 26, 195-205. http://dx.doi.org/10.1016/S08995362(98)00005-0.

Falconer, J.D., (1911): The Geology and Geography of Northern Nigeria, Macmillan and Co. London.

Ferre, E., Caby, R., Peucatt, J. J., Capdevila, R. and Monie, P. (1998).Pan-African postcollisionalferro-potassicgranite and quartz-monzonite plutons of Eastern Nigeria.Lithos, 45, 255278.http://dx.doi.org/10.1016/S0024-4937 (98)00035-8

Grant, N.K. (1970): Geochronology of Pre-Cambrian Basement rocks, Earth and Planet Sci. Lett. 10.29-38.

Grant, N.K., (1971): a compilation of Radiometric ages from Nigeria Jurn. Mm. Geol., 6, 3784.

Harper, C.I.; Shearrer, G.; McCurry; and Wright, Y.B., (1973): K-Ar Retention ages from the pan-African of Northern Nigeria. Geol. Soc. American. Bull. Vol. 34, No. 3, 9 19926.

Ibrahim, A.A. (2003). Geological Setting and the Geochemistry of Iron Formations in the Kazaure Schist Belt, NW Nigeria. Unpublished M.Sc. Thesis. Ahmadu Bello University, Zaria, $89 \mathrm{p}$.

Idris, M.A. (2016). Groundwater Potential Assessment of part of Kazaure Area, Sheet 35 Kazaure SE, Northwestern Nigeria" Unpublished M.Sc. Dissertation, Ahmadu Bello University Zaria, $151 \mathrm{p}$.

McCurry, P., (1970): The Geology of Degree sheet 21 (Zaria) M.Sc. Thesis, Ahmadu Bello University, Zaria.
McCurry, P., (1971): Pan-African Orogeny Northern Nigeria, Bulletin Goel. Soc. American, 82, pp. 35 1-362.

McCurry, P., (1973): Geology of degree sheet 21, Zaria Nigeria. Overseas Geol. And Mm. Res., London, 45.

McCurry, p., (1976): The Geology of the Pre-Cambrian to Lower Palaeozoic rocks in Northern Nigeria - a review In Kogbe

Ogezi, A.E.O., (1977): Geochemistry and Geochronlogy of basement rocks from North-Western Nigeria. Ph.D. thesis, Leeds University.

Okonkwo, C. T., and Winchester, J. A. (2004). Geochemistry of granitic rocks in Jebba area, southwestern inNigeria.J. Min. Geol., 4(2), 95100.

Oyawoye, M.O., (1970): The Basement Complex of Nigeria in African geology (Eds): Desauvogie, T.F.J. and Wuleman, a.J.J. Univ. Ibadan, 62-102.

Rahaman, M. A., Emofurieta, W. O., and Vachette, M. G. (1983). The potassic granites of Igbeti area: furtherevidence of the polycyclic evolution of the Pan-American belt in southwestern Nigeria. Precambrian Res. ,2 (2), 75-92. http://dx.doi.org/10.1016/03019268(83)90059-1.

Rufa'i., S.A., (2011). Geology of sheet 79 Malumfashi south east, geochemistry and mineralization potential ofTudun Kaya - Danzau Area NW, Nigeria.Unpublished M.Sc. Thesis.Ahmadu Bello University, Zaria, 63p.

Russ, W., (1957): The Geology of parts of Niger, Zaria and Sokoto provinces, G.S.N. Bulletin No. 27.

Turner, D.C., (1983): Upper Proterozoic Schist Belts in the Nigerian sector of the pan-African province of West Africa Precambrian Research, 21.

Udo, R.K., (1970): Geographical Regions of Nigeria, Heinemann Educational Books Ltd, pp, 58.

Umeji, A. C., and Caen-Vachette, M. (1984). Geochronology of Pan-African NassarawaEggon and Mkar-Gbokogranites, southeast Nigeria. Precambrian Res., 32, 317-324.http://dx.doi.org/10.1016/03019268(84)90048-2

Van-Breemen, O., Pidgen, R. T., and Bowden, P. (1977).Age and Isotope studies of some PanAfricangranitesfrom north-central Nigeria. Precambrian Res., 4, 307-319. http://dx.doi.org/10.1016/03019268(77)90001-8

Wright, E.P. et al., (1992): The Hydrogeology of Crystalline Basement Aquifers in Africa, The Geological Society London, pp, 22-3. 